\title{
The influence of the Kuroshio Current on place naming on Green Island, Taiwan
}

\author{
Peter Kang \\ National Donghwa University \\ kang@gms.ndhu.edu.tw
}

\begin{abstract}
Green Island off the southeast coast of Taiwan is located along the Kuroshio Current in the western Pacific Ocean. Before the end of Second World War, a variety of place names for Green Island in different languages implied a connection to the Kuroshio Current. These names include exonyms such as Sanasana, Tabaco Migúel, Hóe-sio-tó, and Bonfire, which refer to maritime migration from southern ancestral homelands, the Catholic traffic between Japan and the Spanish Philippines, and shipwreck survivors respectively. Although the name Green Island has been commonly used since 1949 and no longer bears connection to the Kuroshio Current, some eponymous topographic names on the island and adjacent marine toponyms still refer specifically to oceanic flow. These toponyms include coastal place names associated with local memory of major international shipwrecks since the $20^{\text {th }}$ century and fisheries created by the Kuroshio Current.
\end{abstract}

Keywords: Green Island, Kuroshio Current, marine environment, Taiwan, toponyms.

https://doi.org/10.24043/isj. 58

(C) 2018 - Institute of Island Studies, University of Prince Edward Island, Canada.

\section{Introduction}

Islotoponomastics, or the study of place-naming on islands, is among the many approaches to the study of islands. The term toponymic ethnography has thus been proposed to encapsulate the relationship between toponyms, linguistics, and broader cultural and ecological contexts for the understanding of linguistic, cultural, and ecological relationships between people and place (Nash, 2015, p. 147). In terms of islanders or island toponyms in particular, the most salient relationship between people and place in the context of place-naming is arguably the link between humans and the marine environment. Island toponyms applied to areas such as fishing grounds, as well as to the local topography, best illustrate this point. Nevertheless, oceanic currents, one of the fundamental physical elements that constitute the marine environment around any island, may not be properly or directly represented in island toponyms. This is because the toponyms associated with oceanic currents are not always transparent in their meaning, but are instead opaque, with meanings and etymologies that are hidden within their cultural and historical contexts, since not all such naming is assigned according to its lexical connotation (Radding \& Wester, 2010, pp. 395-396).

The current paper will take the Kuroshio Current and the place-naming on Green Island (Taiwan) as a case through which to explore the island toponyms that conceal the relationship between oceanic currents and toponyms per se. In doing so, we will look at not only at the eponymous toponyms used by the islanders but also those nomenclatures left behind by the passing sea navigators in the past. The taxonomy of toponymic research based on island environments could be classified into sea-based vs. terrestrial instances on the primary level; the former is represented by fishing grounds, and the latter is further subdivided 
into topographical features, houses, and roads (Nash, 2015, pp. 151-153). This paper will examine the eponymous toponyms in fishing grounds and topographical categories. For the historical nomenclatures left by passing navigators, we will consider the various place names for Green Island as a whole. In other words, this paper will explore the different toponyms, including exonyms and endonyms, for Green Island, as well as eponymous toponyms used on Green Island, to illustrate their hidden connections to the Kuroshio Current.

\section{Geography and the naming of Green Island}

Green Island (Lü dăo 綠島 in Mandarin Chinese), located approximately $33 \mathrm{~km}$ off the southeast coast of Taiwan, is an island along the Kuroshio Current in the western Pacific Ocean. The island is composed of volcanic andesite and encompasses an area of $15 \mathrm{~km}^{2}$. The local residents currently inhabiting the island are descendants of the Hokkien, a Tâi-gí or Taiwanese-speaking population originally from the southwest coast of Taiwan.

Approximately $43 \mathrm{~km}$ south of Green Island is Orchid Island 蘭嶼, where the local Austronesian population calls themselves the Yami people or the Tao people. The name Yami, meaning North, is an ethnonym given by those living farther south, namely, the people of the Batan Archipelago in the Philippines. Orchid Island is situated approximately $100 \mathrm{~km}$ from the northernmost island of the Batan Archipelago, Mavudis Island. Interestingly, the Yami/Tao people and the Batanese share linguistic similarities and traded weapons, gold, and domesticated animals such as goats and pigs until approximately 300 years ago, when war broke out between them. Green Island was considered a colony of the Yami/Tao people before the Hokkien-speaking people arrived. Northeast of Green Island are the Yaeyama Islands 八重山諸島, the southernmost part of the Ryūkyū 琉球 Archipelago in Japan. The distance between Green Island and the closest island within the Yaeyama Islands, Hateruma 波照間島, is approximately $280 \mathrm{~km}$. There is no apparent evidence linking the people in the Yaeyama Islands to the Yami/Tao people.

Green Island acquired its current name after World War Two, when Taiwan, as well as Green Island, was occupied by the Chinese Nationalist Force, which represented the victorious Allied forces in receiving the official surrender of Japanese forces. American forces played this role in other places along the Kuroshio Current, such as the southern part of the Korean Peninsula, the Ryūkyū Islands, and the Philippines. Approximately four years after the end of the war, on 1 August 1949, Huang Shih-hung 黃式鴻, the magistrate of Taitung (the county in mainland Taiwan that administers Green Island), decreed the renaming of the island as Green Island, a calque of the island's new Chinese name, Lù dăo 綠島. The renaming was believed to overturn the image brought by its original name, Fire-Burnt Island, and replace it with that of a green, fertile island. Even though the renaming was aimed at creating a relatively brighter and more luminous image for the island, ironically, Green Island was utilized as a place of exile for political prisoners jailed by the Chinese nationalists from the late 1940s until the lifting of martial law in 1989. The name Green Island continues to be utilized today.

As matter of fact, in addition to 'Fire-Burnt Island', there are several exonyms for Green Island found in history, and some of them possess elements that reveal a concealed connection with the Kuroshio Current. The literal meanings of these exonyms include 'coconut trees', 'Tobacco Michael', and 'bonfire'.

\section{Coconut Trees: the Austronesian migratory route and ancestral homeland}

The Formosan Austronesians in eastern Taiwan referred to Green Island as Sanasana or Sanasai, which means 'coconut trees'. Sanasai was recorded as the name for Green Island in the early-20 ${ }^{\text {th }}$ century by Japanese scholars, including Inō Kanori 伊能嘉矩 (1867-1925), Utsurikawa Nenozo 移川子之藏 (1884 - 1947), and Mabuchi Tōichi 馬淵東一 (1909- 
1988) when they collected the legends, folktales, histories, and genealogies of the Formosan Austronesians. Sanasai as an island name is mentioned as a stopover in legends concerning the maritime migrations of various Formosan Austronesian ethno-linguistic communities such as the Basay (Basai), the Kavalan (Kebalan), the Amis/Pangcah, and the Puyuma (Pinuyumayan), from their ancestral homeland south of Taiwan. The Austronesian settlements or communities (listed here from south to north) of Arapanai, Kasasikran, Tsipo, Tsikuliean, Takilis, Linau Qauqaut, Torobiawan, and Basai (see Figure 1), are documented to have shared the memory of Sanasai in various legends (Ferrell, 1969, p. 53; 詹素娟, 1998, pp. 37-45). These Formosan Austronesian communities are thought to be closely related to the Polynesians or other Pacific islanders because of shared cultural elements such as the matrilineal and matrilocal sociocultural groupings, ornaments, cosmographic myths and overseas origins. It is believed that the Formosan Austronesians in eastern Taiwan migrated from the Pacific or insular Southeast Asia to Taiwan within the past 3,000 years (Ferrell, 1969, pp. 51-58).

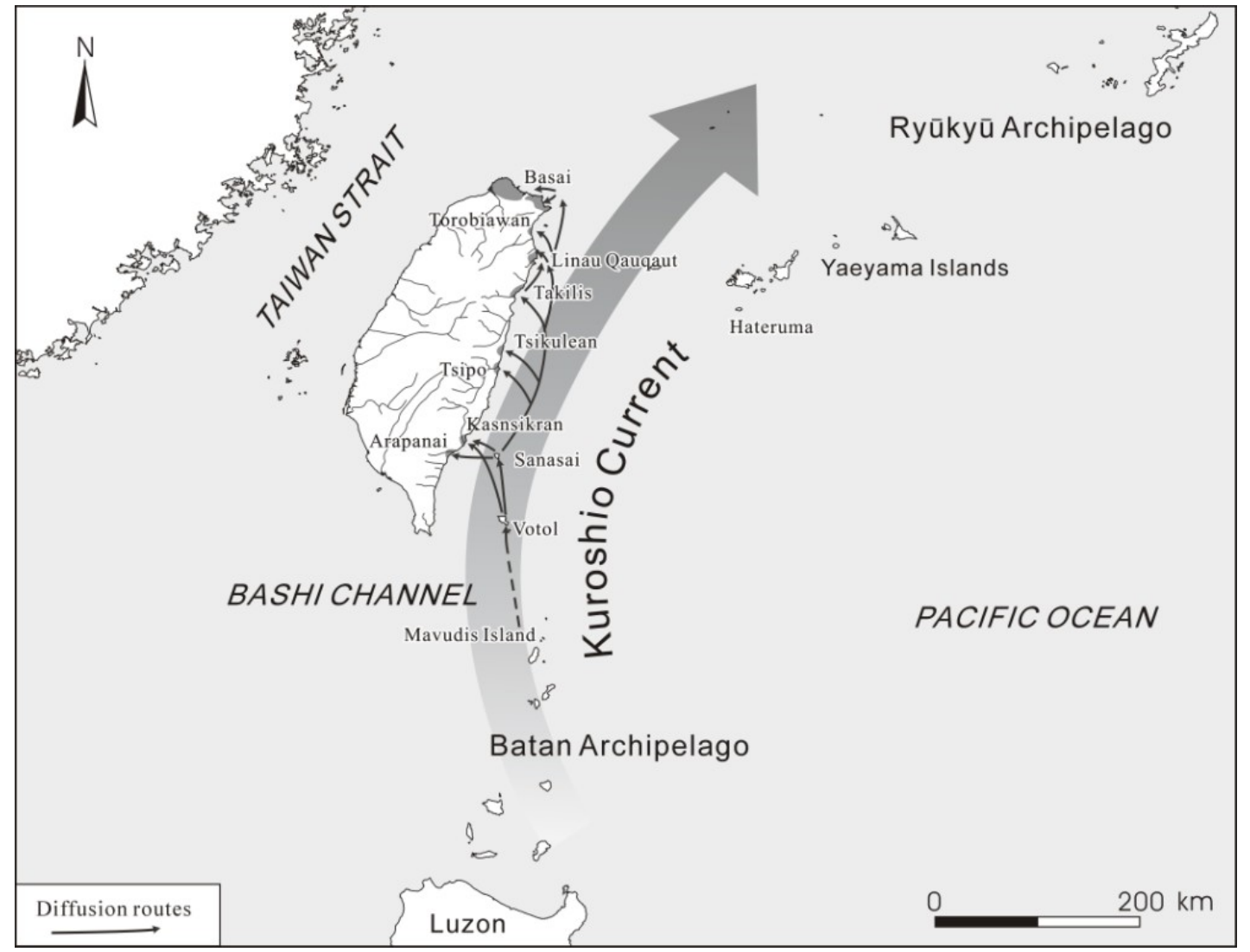

Figure 1: Green Island as Sanasai (C) Peter Kang, 2018)

The geographical distribution of the Sanasai legend primarily follows the northward Kuroshio Current because the human carriers of the legend sailed northward along the eastern coast of Taiwan. Both the place name itself and the people who own the memory of the legend describe the location of Green Island and its relation to the Kuroshio Current. In other words, by naming the island Sanasana, the Formosan Austronesians in eastern Taiwan were reminding themselves both of their ancestral homeland farther south and their maritime migration through the northward Kuroshio Current.

\section{Japanese Catholics? The Early Modern European arrivals}

Following the lucrative spice trade, European merchant sailors arrived in East Asia in the $16^{\text {th }}$ century. The Spanish took Manila in the Philippines as a base for interregional maritime 
trading routes that would eventually connect to the Iberian Peninsula in Europe by way of Acapulco in Mexico. The sea route via the Ryūkyū Islands and Taiwan was used by Japanese Catholics and merchants to facilitate communication between Luzon in the Philippines, and Kyūshū 九州 in Japan. The trip took approximately one month, depending on the currents and wind; however, when sailing from Luzon to Kyūshū, sailors incurred a benefit from the Kuroshio Current (Iaccarino, 2016, p. 6).

The sailors who traveled between Luzon and Kyūshū along the Kuroshio Current called Green Island Tabaco Migúel in addition to the native name Sansana, which is a variation of Sanasana or Sanasai. The actual reason or the inclusion of the name Migúel for Green Island is presently unknown. It might relate to the spread of Catholic beliefs since Migúel is the namesake of the Catholic Archangel Michael. As for the word Tabaco, it was related to nearby Orchid Island. Orchid Island and the uninhabited volcanic islet to its southeast were called Big Tabaco and Small Tabaco respectively. Nevertheless, the name Tabaco Migúel did not appear on the same map with Big Tabaco and Small Tabaco but rather appeared with Bottel Tabakoxima for Orchid Island on the maps highlighting the sea route between Japan and the Philippines (Gommans \& van Dissen, 2010, pp. 242-244). Xima is spelled shima in modern Japanese, meaning island. Thus, this name suggests that the place-naming on European maps was provided by someone associated with the Japanese language. Bottel Tabako is a variation of Botel Tobago, a name widely used on maps for Orchid Island until the $20^{\text {th }}$ century. Therefore, there is little doubt that the names Tabaco Migúel and Bottel Tabakoxima were given by those who extensively utilized the Kuroshio Current to sail between Luzon and Kyūshū (see Figure 2). In other words, the exonyms used by sailors to christen the island disclose the history of those involved in the spreading of Catholicism along the path of the Kuroshio Current, as well as their use of the island for navigation.

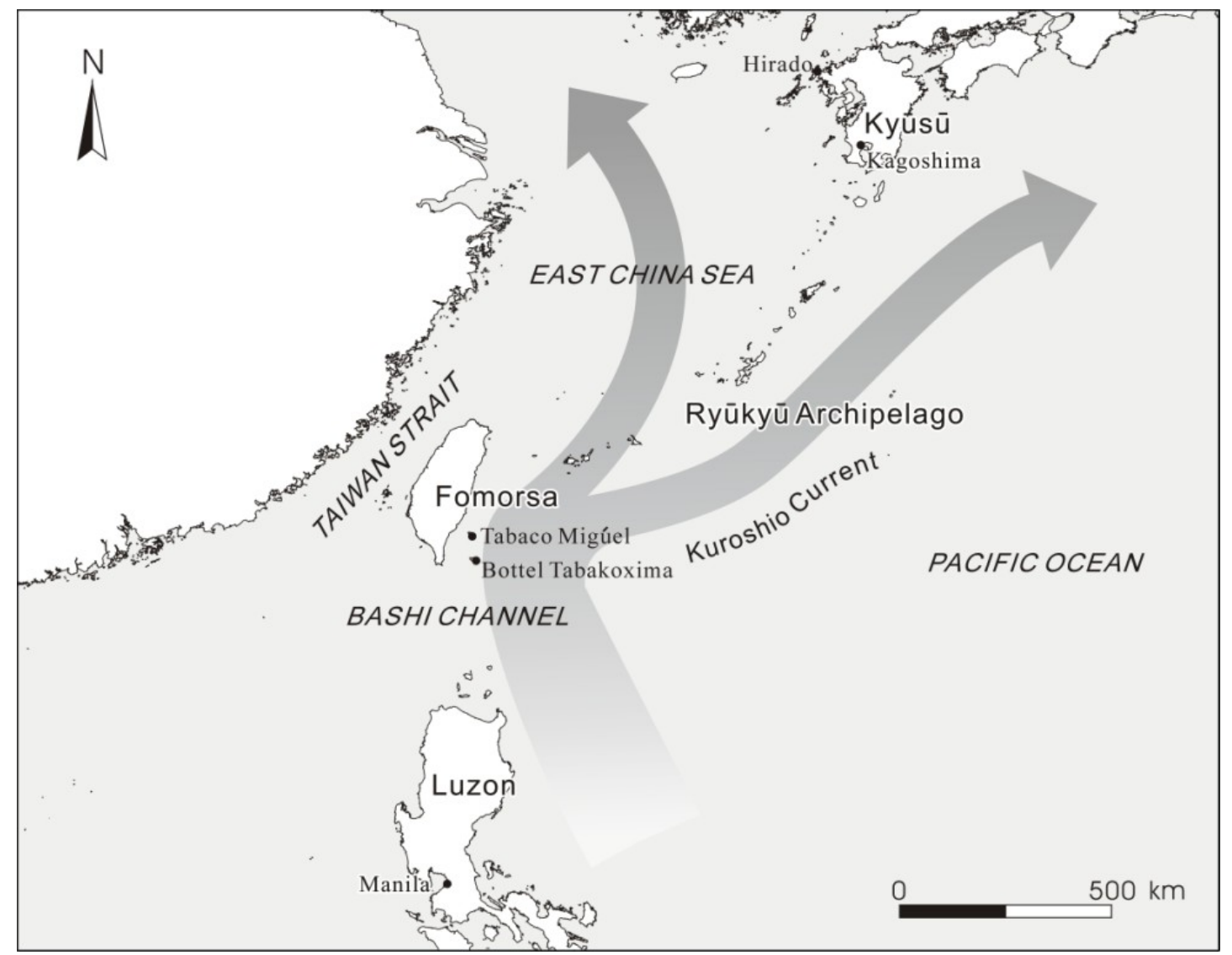

Figure 2: Green Island as Tabaco Migúel. (C) Peter Kang, 2018) 
The Dutch were late-comers to this region during Early Modern maritime navigation. Nevertheless, the Dutch East India Company (Vereenigde Oostindische Compagnie) successfully established a factory on the southwestern coast of Taiwan in 1624. From there, the Dutch gradually dominated the political economy in the lowland areas of Taiwan. Green Island was initially marked as Mauritius Island on Dutch maps.

The first island-wide map of Taiwan by Jacobs Noordeloos in 1625 after a navigation survey, Packan alsoo 'tselve beseijlt is door Jacob Noordeloos, noted I. Maurysy for Green Island (Gommans \& van Dissen, 2010, p. 211). The name was also used later by Jan van Braam in his Map of the Island Formosa and the Islands of the Pescadores (Kaart van het Eylandt Formosa en de Eylanden Piscadores) as Eyl. Moaritius (Vertente et al., 1991, pp. 128-129). The name probably commemorated the company's sailing vessel that first reached the western coast of Australia in 1618. Nevertheless, not only in cartographic works but also in the everyday speech of employees, there was a gradual shift to native names such as Sanna Sanna or Sansana when referring to Green Island. For instance, Map of Chinese coast along the Provinces Canton and Hokkien, also the Island of Formosa (Pas-kaart van de Chineesche kust, langs de Provincien Quantung en Fokien als ook het Eyland Formosa) by Johannes van Keulen noted Sanna Sanna (Vertente et al., 1991, pp. 92-93). Johannes Vingboons in his Map of one part of Chinese Sea and Coast, from Punta Lampa cao to the Overveen Islands, and Island Formosa etc. (Kaart van een gedeelte der Chineese Zee en Kust, van Punta Lampa cao tot de Overveens Eilanden, het Eiland Formosa enz. Hierop komt mede voor: de rivier van Canton, van den mond tot Fangsucis) used the name Sansana (Schilder et al., 2006, pp. 252-253). For the contemporary usage of the native name for Green Island left by the company employees, please see the cases in De Dagregisters van het Kasteel Zeelandia, Taiwan, which left the records of Sanna Sanna (Samma Samma) in the years of 1643 and 1655 (Blussé et al., 1995, p. 134; Blussé et al., 1996, p. 501).

\section{Shipwreck survivors calling for rescue: Bonfire Island}

The Manchu Empire conquered China in the mid- $17^{\text {th }}$ century and later expanded its imperial control to the lowland areas of Taiwan in the late- $17^{\text {th }}$ century. The eastern part of Taiwan, being separated by the Central Mountain Range, was not under imperial control, nor was Green Island, until the late- $19^{\text {th }}$ century.

Green Island was noted by chorography and cartographical works of the Manchu Empire in the $19^{\text {th }}$ century as Huǒshāo Yǔ 火燒嶼, meaning Fire-Burnt Island. Examples include the maps Táiwān qiánhòu shān Yútú 臺灣前後山輿圖 (1878) and Táiwān qiánhòu shān quán tú 臺灣前後山全圖 (1880). Huoshao Yu is the literal translation of Hóe-sio-tó 火燒 島, a name given by Hokkien-speaking fishers and traders who passed the island in their travels and a number of whom ultimately settled on the island. The date of the earliest arrival of Hokkien-speaking people on Green Island is unknown to us. The Dutch East India Company logged an observation of possible human activity on the island in the year of 1655 by noting catching sight of a bonfire. The Dutch suspected that this was evidence of Hokkien traders who used the island as a stopover to St. Laurens (today's So- 0 蘇澳) on the northeastern coast of Taiwan (Blussé et al., 1996, p. 501).

The Fire-Burnt Island toponym was once said to represent a rapid change in the island's ecology in the $19^{\text {th }}$ century after the arrival of the Hokkien-speaking population, whose logging industry caused the deforestation of Green Island. Nevertheless, some argue that the name was derived from cases of shipwrecked crew members who set fires to call for rescue. The strength of the Kuroshio Current increases rapidly between Green Island and mainland Taiwan, which has occasioned numerous sailing accidents (李玉芬, 2014, pp. 140-141, pp. 148-149, p. 148n34). Contemporary Europeans commonly recorded the name Bonfire Island, which is another literal translation of Hóe-sio-tó, in addition to the old Austronesian name, 
Sanasana, in their cartographic works and navigation logs. Sanasana might be spelled Samasana or Samasand and was in fact more widely used than Bonfire by the Europeans. For instance, in his article, William Campbell used the term Samasana (Campbell, 1896, p. 387), whereas John D. Clark marked Green Island as Samasand (Clark, 1896, p. 100). In contrast, the Austronesian name is completely absent in the records of the Manchu Empire.

The Japanese Empire took over Taiwan, including Green Island, after defeating the Manchu Empire in 1895. Since then, Green Island has been labeled Kashō-tō 火焼島 after the calque Hóe-sio-tó. All the names in different languages bearing the meaning Fire-Burnt Island or Bonfire Island were also used until the disintegration of the Japanese Empire following Second World War.

In terms of our interest in the connection between the naming of the island and the Kuroshio Current, the exonym Hóe-sio-tó, as well as its contemporary equivalent translations (Huǒshāo Yǔ in Mandarin, Bonfire Island in English, and Kashō-tō in Japanese) reflects how the Hokkien-speaking seafarers perceived the island as a place of numerous shipwrecks that were caused by the sudden increase in the strength of the Kuroshio Current.

Table 1: Place names for Green Island and their connection to the Kuroshio Current.

\begin{tabular}{|c|c|c|}
\hline Place Names & Language & Connection \\
\hline Sanasana & Formosan Austronesian & Stopover during maritime migration \\
\hline Tabaco Migúel & Spanish & $\begin{array}{l}\text { Catholic traffic between Japan and Spanish } \\
\text { Philippines }\end{array}$ \\
\hline Hóe-sio-tó & Hokkien & Shipwreck survivors \\
\hline Bonfire & English & Shipwreck survivors \\
\hline
\end{tabular}

\section{Place names and marine toponyms on Green Island}

In addition to the exonyms of the island itself, several topographic names and marine toponyms on Green Island given by the local Hokkien-speaking fishermen dwelling on the island can be traced back to the influence of the Kuroshio Current. The topographic names on land are predominantly associated with major international shipwreck incidents, whereas the associated marine toponyms are mostly related to the fisheries with ties to the abundant migratory fish stocks carried by the Kuroshio Current (see Figures 3 and 4).

O-hî-khut 烏魚窟, or Den of Mullets, on the northern coast of Green Island refers to a sandy beach that periodically turned into a small lagoon at low tide. The place name itself indicates that mullets would be found in the lagoon. On 11 December 1937, the SS President Hoover hit a nearby reef en route from Kobe to Manila and subsequently sank. The spilled oil filled the lagoon, turning it into a pool of greasy dirt. The islanders immediately renamed the sporadic lagoon O-iû-khut 烏油窟, or Den of Tarnished Oil (趙仁方\&林登榮, 2014, p. 201). The change of topographic names by local residents was facilitated by the close similarity in

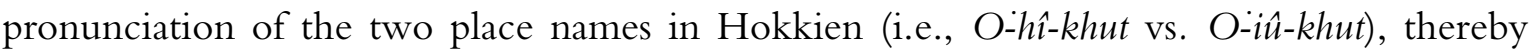
making the colloquial transition from mullets to tarnished oil relatively simple for locals even though the connotations of the two place names are quite different.

Two place names on the southern coast of Green Island are connected to shipwreck incidents, namely, Kòng-phòa-hoan-chûn 摃破番船 (Fracturing of Foreign Vessels) and Hoan-chûn$p h \overline{\boldsymbol{l}}^{n}$ 番船鼻 (Nose of Foreign Vessels). The term $p h \overline{\boldsymbol{l}}^{n}$, literally translated as nose, is widely used as an anthropomorphic metaphor in Hokkien to refer to a cape in coastal geomorphology. In addition, islanders dubbed a reef near Hoan-chûn-ph $\overline{\boldsymbol{I}}^{n}$ Hoan-chûn-phī pàng-chiáu-sái-ta 番船鼻 放鳥屎礁 (Reef of Bird Excrement Dropped from the Nose of Foreign Vessel), to commemorate the 1992 sinking of the Greek cargo ship Pegasus (趙仁方\&林登榮, 2014, p. 224, p. 237). 


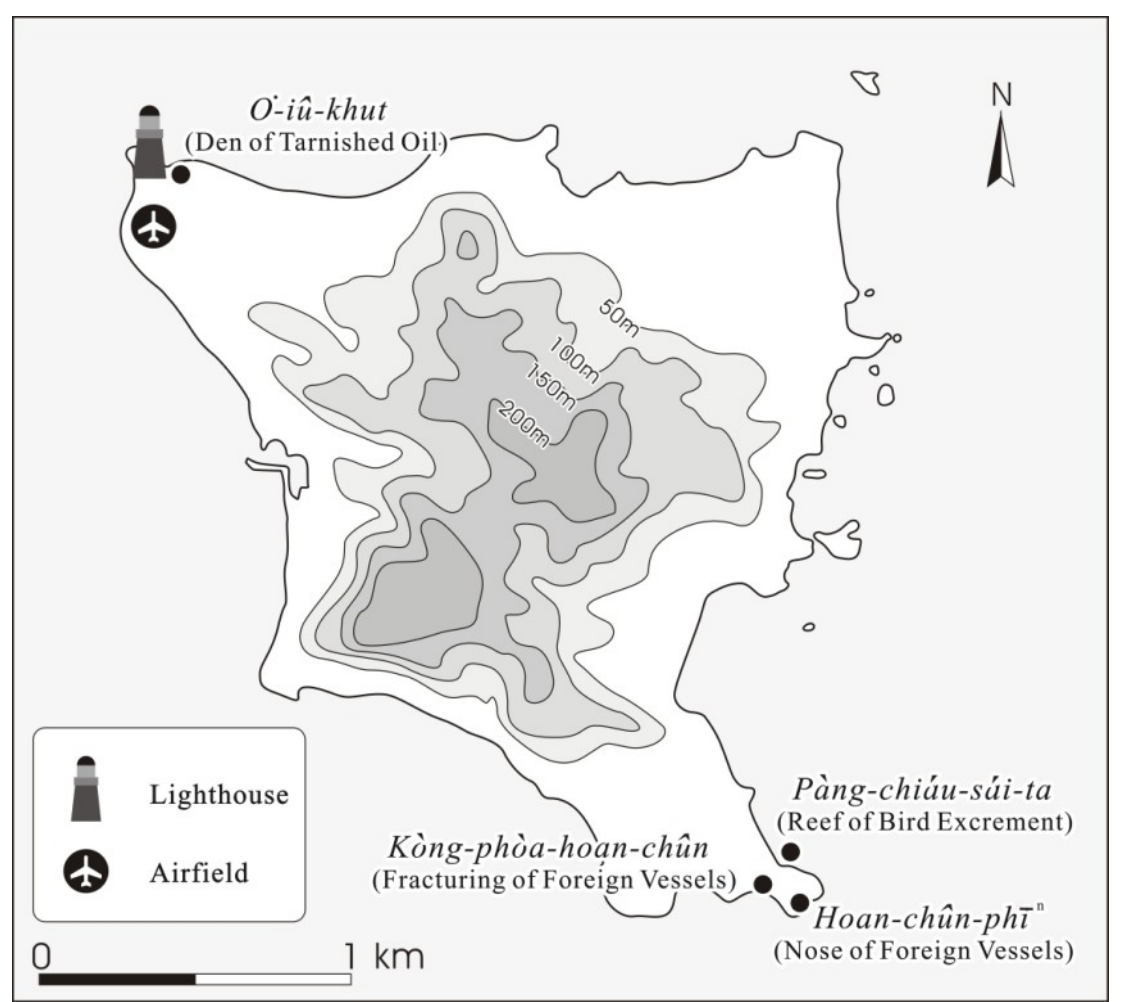

Figure 3: Place names related to shipwrecks. (C) Peter Kang, 2018)

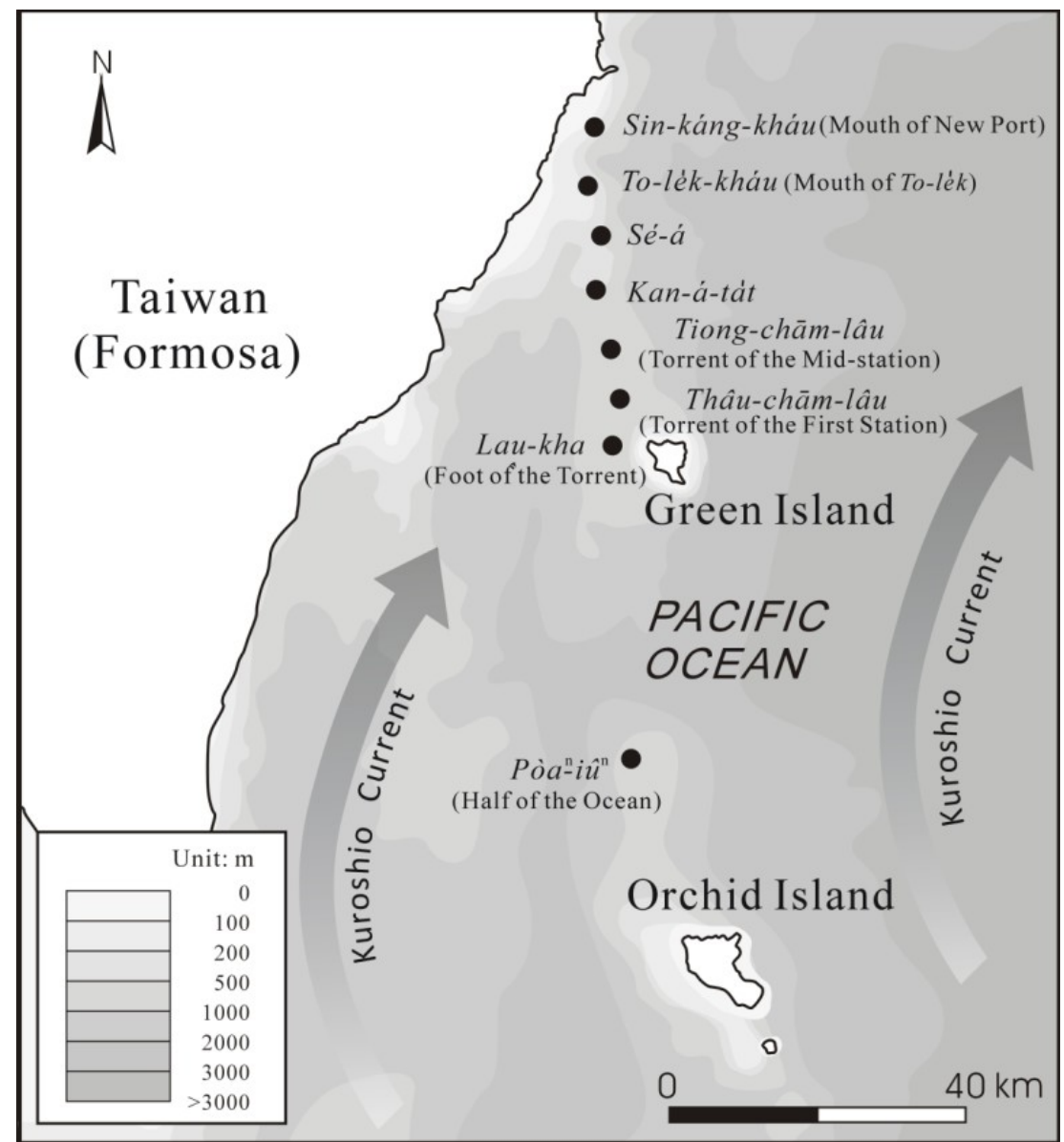

Figure 4: Marine toponyms related to fisheries. (C) Peter Kang, 2018) 
The Kuroshio Current runs at different speeds on either side of Green Island. The flow on the west side runs faster than that on the east. As a result, it has earned the name Thàu-lâu 透流 (Riptide) among local fishermen. Thàu-lâu was also called Lâu-kha 流腳 (The Foot of a Torrent), which fishermen identify as one of Green Island's in-shore fisheries. As the Kuroshio Current runs northward, the local fishermen named the riptide off the southwestern coast of Green Island Lâu-thâu 流頭 (The Head of a Torrent) and that off the northwestern coast Lâu-bé 流尾 (The Tail of a Torrent). In other words, islanders use head and tail metaphors to designate the direction of the current in their place-naming, while foot refers to fishing ground (趙仁方\&林登榮, 2014, p. 239).

Starting from Lâu-kha fishery, local fishermen name the fishing grounds going northwestward from Green Island to mainland Taiwan Thâu-chām-lâu 頭站流 (The Torrent of the First Station), Tiong-chām-lâu 中站流 (The Torrent of the Mid-Station), Kan-á-ta't 䂥仔達 (Corkscrew), Sé-á 洗仔, To-lek-kháu 都歷口 (The Mouth of To-lek), and Sin-káng-kháu 新港口 (The Mouth of New Port). The two fisheries closest to Green Island are named after the riptide, as in the case of Lâu-kha, and the two fisheries closest to Taiwan are named after adjacent places on the mainland. In addition, halfway between Green Island and Orchid Island is the

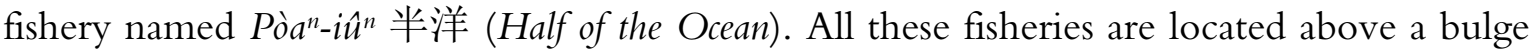
in the seabed terrain, where the northward Kuroshio Current is disturbed and brings shoals of fish (趙仁方\&林登榮, 2014, pp. 239-230).

Table 2: Place names around and on Green Island and their connection to the Kuroshio Current.

\begin{tabular}{lll}
\hline Place Name & English Equivalent & Connection \\
\hline O-î̀-khut & Den of Tarnished Oil & Major international shipwreck \\
Kòng-phòa-hoan-chûn & Fracturing of Foreign Vessels & Major international shipwreck \\
Hoan-chûn-phī ${ }^{n}$ & Nose (Cape) of Foreign Vessels & Major international shipwreck \\
Lâu-kha & Foot of a Torrent & Fishery \\
Thâu-chām-lâu & Torrent of the First Station & Fishery \\
Tiong-chām-lâu & Torrent of the Mid-station & Fishery \\
Kan-á-ta't & Corkscrew & Fishery \\
Sé-á & & Fishery \\
To-lèk-kháu & Mouth of To-lèk & Fishery \\
Sin-káng-kháu & Mouth of New Port & Fishery \\
Pòa $a^{n}-i \hat{u}^{n}$ & Half of the Ocean & Fishery \\
\hline
\end{tabular}

\section{Conclusion}

Prior to the end of Second World War, four exonyms for Green Island implied its connection to the Kuroshio Current: Sanasana, Tabaco Migúel, Hóe-sio-tó, and Bonfire. The last one is the literal translation of the third exonym, while the first of these refers to the maritime migration of the Formosan Austronesians to eastern Taiwan from their southern ancestral homelands along the path of the Kuroshio Current. The designation used in the Formosan Austronesian languages bears the memory of these people's history. The second denotes the Catholic traffic along the path of the Kuroshio Current between Japan's Kyūshū and Luzon in the Spanish Philippines during the late- $16^{\text {th }}$ and early- $17^{\text {th }}$ centuries. The Spanish-language designation illustrates the religious ambitions of the once-formidable Iberian Empire. The final two exonyms refer to shipwreck survivors calling for rescue, and the appellation reveals the danger perceived by Hokkien seafarers.

Although the exonym Green Island has been in use since 1949, it bears no connection to the Kuroshio Current. Nevertheless, some place names on the island and nearby marine 
toponyms given by the Hokkien-speaking islanders still demonstrate the influence of the oceanic flow. The topographic names along the coast, where the current is strong, are associated with the local inhabitants' memories of major foreign shipwrecks that have occurred since the $20^{\text {th }}$ century. Interestingly, all the eponymous toponyms on Green Island and the exonym for Green Island in Hokkien reference shipwrecks. They recollect either the wrecks themselves or survivors of shipwrecks. This points to the Hokkien-speaking people's perception of the marine environment created by the Kuroshio Current.

However, not all the eponymous toponyms in Hokkien bearing a connection to the Kuroshio Current around Green Island demonstrate this fearful attitude toward the sea. In fact, the eponymous marine toponyms are mostly based on the fisheries created by the Kuroshio Current. These names for fishing grounds near Green Island are descriptive in nature and denote the direction of ocean currents (e.g. Foot of a Torrent), as well as their sequential order in terms of distance within the island-centric perspective (e.g. Torrent of the First Station, Torrent of the Mid-Station, Half of the Ocean). The fisheries situated far from the island and near mainland Taiwan were named after known land marks, such as adjacent place names (e.g. Mouth of To-lek, Mouth of New Port). The hydronyms of relatively smaller fishing grounds located near the shore and named by various individual islanders are mostly transient (Nash, 2012, pp. 76-77, p. 80). Their ephemerality is primarily due to changes in terrestrial markers or fish movements and clustering patterns (Nash, 2015, pp. 152-153). In contrast, the stability of the Kuroshio Current and toponymic markers contribute to the persistence of major fishing ground names around Green Island.

\section{Acknowledgements}

I would like to thank Dr. Pek Wee Chuen for his assistance with excellent cartographic works. I am also greatly indebted to the valuable comments from the anonymous reviewer and the editor. Any errors and misinterpretations in the article remain only my own.

\section{References (English)}

Blussé, L., Milde, W.E., \& Ts'ao Yung-ho (Eds.). (1996). De Dagregisters van het Kasteel Zeelandia, Taiwan, deel III, 1648-1655. Gravenhage: M. Nijhoff.

Blussé, L., Milde, W.E., \& Ts'ao Yung-ho (Eds.) (1995). De Dagregisters van het Kasteel Zeelandia, Taiwan, deel II, 1641-1648. Gravenhage: M. Nijhoff.

Campbell, W. (1896) The island of Formosa: its past and future. Scottish Geographical Magazine, 12(8), 385-399. https://doi.org/10.1080/00369229608732903

Clark, J.D. (1896) Formosa. Shanghai: Shanghai Mercury Office.

Ferrell, R. (1969). Taiwan Aboriginal groups: problems in cultural and linguistic classification. Nankang: Academia Sinica.

Gommans, J.J.L., \& van Dissen, J.R. (2010). Grote Atlas van de Verenigde Oost-Indische Compagnie, deel VII: Oost-Azië, Birma tot Japan \& Supplement. Voorburg: Asia Maior.

Iaccarino, U. (2016) Sangleys, Japones, and Casados: an overview on the actors of the SinoJapanese trade in the Philippines between the $16^{\text {th }}$ and $17^{\text {th }}$ centuries. Paper presented at Academia Sinica conference, 20 June, Taipei, Taiwan.

Nash, J. (2015). Island placenaming and insular toponymies. Names, 63(3), 146-157. https://doi.org/10.1080/03721426.2012.10887165

Nash, J. (2012). An insular toponymy: place-naming on Dudley Peninsula, Kangaroo Island. Transactions of the Royal Society of South Australia, 136(2), 67-98. https://doi.org/10.1080/03721426.2012.10887165 
Radding, L., \& Western, J. (2010). What's in a name? Linguistics, geography, and toponyms. The Geographical Review, 100(3), 394-412. https://doi.org/10.1111/j.19310846.2010.00043.x

Schilder, G., Moerman, J., Ormeling, F., van den Brink, P., \& Ferwerda, H. (2006). Grote Atlas van de Verenigde Oost-Indische Compagnie, deel I. Voorburg: Asia Maior.

Vertente, C., Hsu Hsueh-chi, \& Wu Mi-ch'a (1991) The authentic story of Taiwan: an illustrated history, based on ancient maps, manuscripts and prints. Knokke: Mappamund.

\section{References (Chinese)}

李玉芬.第二章: 清代的入墾. 臺東縣綠島鄉誌. 臺東: 綠島鄉鄉公所, 2014, 140-249.

詹素娟. Sanasai 傳說圈的族群歷史圖像. 平埔族群的區域研究論文集. 南投: 臺灣省文 獻委員會, 1998, 29-59.

趙仁方, 林登榮. 第三篇: 地名篇. 臺東縣綠島鄉誌. 臺東: 綠島鄉鄉公所, 2014, 180-241. 